\title{
An assessment of toxic metals in soda mine tailings and a native grass: a case study of an abandoned Nyala Magnesite mine, Limpopo, South Africa
}

\author{
M. N. Jeleni ${ }^{2}$, J. R. Gumbo ${ }^{1}$, C. Muzerengi ${ }^{2}$ \& F. A. Dacosta ${ }^{2}$ \\ ${ }^{I}$ Department of Hydrology \& Water Resources, \\ University of Venda, South Africa \\ ${ }^{2}$ Department of Mining and Environmental Geology, \\ University of Venda, South Africa
}

\begin{abstract}
The purpose of the study was to assess the level of toxic metals $(\mathrm{Cd}, \mathrm{Co}, \mathrm{Cu}, \mathrm{Cr}$, $\mathrm{Mn}, \mathrm{Pb}, \mathrm{Ni}$ and $\mathrm{Zn}$ ) in an abandoned Nyala mine tailings dams and in Aristida congesta, a native grass. The mean value of toxic metals in the mine tailings soils 1 were: $\mathrm{Mn}(498.78 \pm 2.42 \mathrm{mg} / \mathrm{kg}) ; \mathrm{Ni}(114.62 \pm 2.64 \mathrm{mg} / \mathrm{kg}) ; \mathrm{Cr}(81.30 \pm$ $3.03 \mathrm{mg} / \mathrm{kg}) ; \mathrm{Co}(77.10 \pm 0.46 \mathrm{mg} / \mathrm{kg}) ; \mathrm{Zn}(58.31 \pm 0.90 \mathrm{mg} / \mathrm{kg}) ; \mathrm{Cu}(26.32$ $\pm 0.12 \mathrm{mg} / \mathrm{kg}) ; \mathrm{Pb}(14.13 \pm 0.70 \mathrm{mg} / \mathrm{kg})$ and $\mathrm{Cd}(10.00 \pm 0.00 \mathrm{mg} / \mathrm{kg})$ respectfully. The mean value of toxic metals in the mine tailings soils 2 were: $\mathrm{Ni}$ $(959.31 \pm 9.72 \mathrm{mg} / \mathrm{kg}) ; \mathrm{Mn}(424.24 \pm 0.76 \mathrm{mg} / \mathrm{kg}) ; \mathrm{Co}(63.44 \pm 0.83 \mathrm{mg} / \mathrm{kg}) ; \mathrm{Cr}$ $(56.52 \pm 0.69 \mathrm{mg} / \mathrm{kg}) ; \mathrm{Zn}(46.26 \pm 0.92 \mathrm{mg} / \mathrm{kg}) ; \mathrm{Cu}(22.03 \pm 0.64 \mathrm{mg} / \mathrm{kg}) ; \mathrm{Pb}$ $(17.57 \pm 0.87 \mathrm{mg} / \mathrm{kg})$ and $\mathrm{Cd}(1.13 \pm 0.12 \mathrm{mg} / \mathrm{kg})$. The $\mathrm{pH}$ of mine tailings soils 1 was $7.97 \pm 0.06$ and electrical conductivity was $4.92 \pm 0.06 \mathrm{mS} / \mathrm{cm}$. The $\mathrm{pH}$ of mine tailings soils 2 was $8.94 \pm 0.06$ and electrical conductivity was $1.88 \pm 0.10$ $\mathrm{mS} / \mathrm{cm}$. A. congesta, was growing in abundance in mine tailings soils 2 and none in mine tailings soils 1 . The reason may be due to cumulative toxic metals and $\mathrm{Ni}$ which was eight times more in mine tailings soils 1 . A. congesta accumulated the toxic metals (sum of roots, stem and leaves) as follows: $\mathrm{Cr}(184.55 \mathrm{mg} / \mathrm{kg}$ ); $\mathrm{Mn}(104.60 \mathrm{mg} / \mathrm{kg}) ; \mathrm{Ni}(95.99 \mathrm{mg} / \mathrm{kg}) ; \mathrm{Co}(18.66 \mathrm{mg} / \mathrm{kg}) ; \mathrm{Zn}(10.13 \mathrm{mg} / \mathrm{kg}) ; \mathrm{Cu}$ $(8.93 \mathrm{mg} / \mathrm{kg}) ; \mathrm{Pb}(4.40 \mathrm{mg} / \mathrm{kg})$ and $\mathrm{Cd}(0.93 \mathrm{mg} / \mathrm{kg})$. The bioaccumulation coefficient was 2.27 which mean that $A$. congesta is a hyperaccumulator for $\mathrm{Cr}$.
\end{abstract}


Thus $A$. congesta is recommended to rehabilitate the mine tailings and provide a cover against wind and water erosion.

Keywords: trace and toxic metals, phytoremediation, native grass Aristida congesta, abandoned soda mine tailings.

\section{Introduction}

Mine tailings are one of the major environmental contaminants. According to Truong [1], there have been increasing concerns throughout the world about the contamination of the environment by the mining and tailings disposal activities. The alarming rate of these concerns is compounded by the fact that majority of the contaminants contain high levels of toxic metals or alkalinity, sodicity, salinity and acidity which can affect vegetation, animals and humans living in the vicinity, in the adjacent or downstream of the polluted sites. Furthermore, mine tailings are usually characterized by fine particle sized materials which can readily be eroded or leached out and according to Adriano [2]. The leaching and water/wind erosion are usually the causes of contamination in areas beyond the contaminated sites.

In Namibia, there are grass such as Stipagrostis uniplumis and the herb species that were absent from the most toxic ground but Aristida congesta was observed to grow on toxic ground (Cole and Smith [3]). The metal bioaccumulation by plants (grass) contributes to the circulation of heavy metals in the food chain through their active and passive absorption by plant (grass) tissues subsequently leading to grazing by animals and consumption by humans. Species growing within mineralized zones tend to exhibit high levels of heavy metals in their areal tissues. Furthermore, studies have shown variance of species with particular bioaccumulative capacities with respect to one or more several heavy metals. Thereby serving as bioindicators of contaminated sites or used as heavy metal prospecting (Wislocka et al. [4]).

The vegetation cover play a large part in suppressing the environmental impacts such as sedimentation, erosion, windblown dust and surface runoff in abandoned mines and mine tailings sites (Truong and Baker [5]). Fertile soils supply plants with all of the trace elements essential for growth. Conversely many trace elements, including all of the micronutrients, can reach concentrations in soils that are toxic to plants and microorganisms (McBride [6]). Moreover, magnesite tailings are inhospitable to plants, since they can induce alkaline and sodic soil which may inhibit or suppress the growth of vegetation. Alkalinity of magnesite tailings is of more concern and toxicities from chromium, nickel, manganese, copper, zinc, lead and chromium may be a problem on vegetation (Bauer et al. [7]).

Nyala Magnesite Mine is an abandoned site that is located at Zwigodini area, in an arid region, which falls under Mutale local Municipality in Limpopo province, South Africa. The abandoned Nyala Magnesite mine is located at a flat land, but the surrounding area is also made up of valleys that recharge water during enough rains. The presence of valleys around the abandoned Nyala Magnesite Mine disturbs the flatness of the area causing it to be undulating. The 
vegetation type that dominates the Klein Tshipise area is arid Mountain Bushveld and Mopane Woodlands (Thulamela Municipality [8]). The perennial rivers, Mutale and Luvuvhu, drain the study area, with the former being located near the Nyala Magnesite mine. The nearby rural communities depend on surface water and groundwater (boreholes) for their domestic and livestock watering (DWAF [9]).

The main objective was to assess the level of toxic and heavy metals in the Nyala mine tailings and in a native grass, Aristida congesta, which was founding thriving in one of the mine tailings soils. The specific objectives were: to determine the $\mathrm{pH}$ and electrical conductivity of the mine tailing soils and its contribution to the promotion of plant growth; to determine the level of toxic metals in the mine tailings soils and to determine the level of toxic metals in different sections of $A$. congesta and its potential in phytoremediation of exposed mine tailings surfaces.

\section{Materials and methods}

\subsection{Sampling and sample processing}

The mine tailings soils and grass samples (A. congesta) were collected at mine tailings $1(-22.53424 ; 30.61081)$ and mine tailings $2(-22.53161 ; 30.62337)$. The collected samples were sealed in plastic sachets, labelled with date of sampling, GPS coordinates and then sent to University of Venda laboratory for further processing. The samples were processed as procedure of Mulugisi et al. [10] and then subjected to acid digestion (APHA [11]).

\subsection{The determination of $\mathrm{pH}$ and electrical conductivity and analysis of metals in mine tailings soils and grass samples}

The $\mathrm{pH}$ and electrical conductivity of the mine tailings soil were determined following the procedure of Mulugisi et al. [10]. The collected soil and grass samples were analyzed by Varian Spectra AA 110 Flame Atomic Absorption Spectrometer (220/880 series) with deuterium background corrector to determine the following metals: $\mathrm{Ni}, \mathrm{Zn}, \mathrm{Co}, \mathrm{Zn}, \mathrm{Cd}, \mathrm{Mn}, \mathrm{Pb}$ and $\mathrm{Cr}$ following standard methods (APHA [11]). All chemical analyses were conducted in triplicate.

\subsection{Data analysis}

The analytical raw data was processed as per procedure of Mulugisi et al. [10] and statistical analysis was carried out with single factor ANOVA.

\section{Results and discussion}

\subsection{Visual observation}

At mine tailings 1, there were no observed growth of plants or grass, probably this was due to inhibition of plants or grass (Figure 1(A)). Whereas mine tailings 1, there were observed growth of plants and Aristida congesta was growing in abundance at mine tailings 2 (Figure 1(B)). 

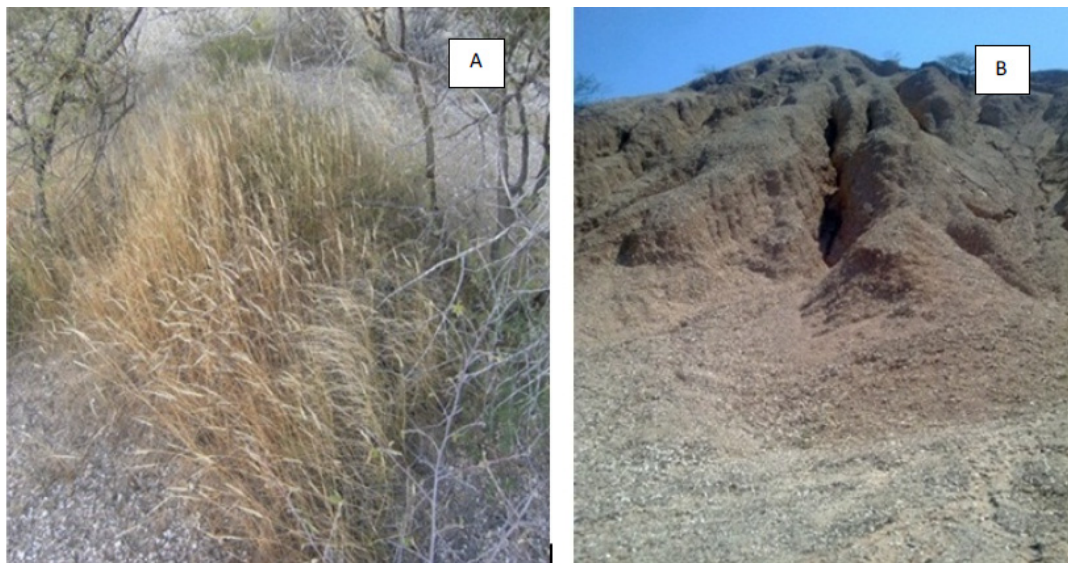

Figure 1: (A) Extensive growth of Aristida congesta grass at mine tailings 1and (B) Exposed sections of mine tailings 2 showing extensive erosion of bare surfaces.

\subsection{The variation of $\mathrm{pH}$ and electrical conductivity of mine tailings and their impact on plant growth}

The $\mathrm{pH}$ and electrical conductivity (EC) of mine tailings 1 soil was alkaline with high electrical conductivity whereas that of mine tailings 2 was highly alkaline and low electrical conductivity (Table 1). At the $\mathrm{pH}$ of 8.94 and EC mean of 1.88 $\mathrm{mS} / \mathrm{cm}$ the soil was inhibitory to plant growth, since there was no bioavailability of plant nutrients (Van Rensburg et al. [12]) and this soil was classified as sodic soil which provides poor structure for plant growth (Kamphorst and Bolt [13]). While the $\mathrm{pH}$ of 7.97 and $\mathrm{EC}$ of $4.92 \mathrm{mS} / \mathrm{cm}$, the soil promoted plant growth, as indicated by presence of Aristida congesta and the soil was classified as saline soil which provides good structure for plant growth (Kamphorst and Bolt [13]). The $\mathrm{pH}$ findings are in agreement with the study of Larcher [14] who found that most plants have a broad optimum range between weak acidity and weak alkalinity, between $\mathrm{pH} 3.5$ and 8.5 .

Table 1: The concentrations of toxic and trace metals in mine tailings.

\begin{tabular}{|c|c|c|c|c|c|c|c|c|}
\hline & \multicolumn{5}{|c|}{ Mine tailings 1} & \multicolumn{3}{|l|}{ Mine tailings 2} \\
\hline & Mean & (SD) & Min & Max & Mean & (SD) & Min & Max \\
\hline $\mathrm{pH}$ & 7.97 & 0.06 & 7.90 & 8.01 & 8.94 & 0.06 & 8.90 & 9.00 \\
\hline $\mathrm{EC}(\mathrm{mS} / \mathrm{cm})$ & 4.92 & 0.06 & 4.88 & 4.99 & 1.88 & 0.01 & 1.87 & 1.88 \\
\hline \multicolumn{9}{|c|}{ metal concentration $(\mathrm{mg} / \mathrm{kg})$} \\
\hline Cd & 10.00 & 0.00 & 10.00 & 10.00 & 1.13 & 0.12 & 1.00 & 1.20 \\
\hline $\mathrm{Pb}$ & 14.13 & 0.70 & 13.39 & 14.79 & 17.57 & 0.87 & 16.58 & 18.17 \\
\hline $\mathrm{Ni}$ & 114.62 & 2.64 & 67.97 & 171.92 & 959.31 & 9.72 & 948.60 & 967.57 \\
\hline Mn & 498.78 & 2.42 & 497.38 & 501.58 & 424.24 & 0.76 & 423.37 & 424.77 \\
\hline Co & 77.10 & 0.46 & 77.37 & 76.57 & 63.44 & 0.83 & 62.51 & 64.11 \\
\hline $\mathrm{Cr}$ & 81.30 & 3.03 & 78.57 & 84.56 & 56.52 & 0.69 & 55.72 & 56.92 \\
\hline $\mathrm{Cu}$ & 26.32 & 0.12 & 26.19 & 26.39 & 22.03 & 0.64 & 21.57 & 22.77 \\
\hline $\mathrm{Zn}$ & 58.31 & 0.90 & 57.37 & 59.17 & 46.26 & 0.92 & 45.73 & 47.33 \\
\hline & \multicolumn{4}{|c|}{ Means (Standard deviation), $\mathrm{n}=3$} & \multicolumn{4}{|c|}{ Means (Standard deviation), $\mathrm{n}=3$} \\
\hline
\end{tabular}


The results on the $\mathrm{pH}$ and $\mathrm{EC}$ of the mine tailings 1 and 2 indicated that there was a statistically significant different $(\mathrm{p}<0.05)$. The differences in $\mathrm{EC}$ and $\mathrm{pH}$ between mine tailings may be probably due to that the tailings materials were not from the same mine pit and each mine pit probably consists of its own geochemical characteristic, therefore the inhomogeneous geochemical terrains could have caused the two tailings to differ.

\subsection{The concentration of metals in mine tailings and their impact on growth of native grass: Aristida congesta}

The study showed that the metals were distributed in different sections of native grass, $A$. congesta, which was thriving on mine tailings 1 (Figure 1A; Table 2). In the absence of control samples, we may presume that the metals probably originated from the mine tailings 1 (Table 1). This is further supported by the absence of $A$. congesta on mine tailings 2 and this was attributed to adverse growing conditions of high $\mathrm{pH}$ (alkaline) conditions. The concentration of analysed trace elements in mine tailings that promotes vegetation growth were higher than in tailings that inhibit vegetation growth with exceptions of $\mathrm{Ni}$ and $\mathrm{Pb}$ (Table 1) and these exceptions could have been through the leaching of sodic soil or low saline (i.e. low EC) which caused the $\mathrm{pH}$ to rise in the soil and consequently led to the mobilisation of elevated concentration of $\mathrm{Ni}$ and $\mathrm{Pb}$ as indicated by Kamphorst and Bolt [13]. The elevated concentration of $\mathrm{Ni}$ and $\mathrm{Pb}$ is also in agreement with the notation that trace elements (i.e. $\mathrm{Ni}, \mathrm{Cu}, \mathrm{Mn}$ and $\mathrm{Zn}$ ) are essential for plant growth at less than $10 \mathrm{ppm}$ (Lasat [15]) but at elevated concentration are toxic and can suppress or inhibit plant growth.

Table 2: $\quad$ The distribution of metals in different sections of the A. congesta grass.

\begin{tabular}{|c|c|c|c|c|c|c|c|c|c|c|c|c|}
\hline \multirow{2}{*}{$\begin{array}{l}\text { metal concentration } \\
(\mathrm{mg} / \mathrm{kg})\end{array}$} & \multirow{2}{*}{$\begin{array}{l}\text { Roots } \\
\text { Mean }\end{array}$} & \multirow[b]{2}{*}{ (SD) } & \multirow[b]{2}{*}{ Min } & \multirow[b]{2}{*}{ Max } & \multirow{2}{*}{$\begin{array}{l}\text { Stem } \\
\text { Mean }\end{array}$} & \multirow[b]{2}{*}{ (SD) } & \multirow[b]{2}{*}{ Min } & \multirow[b]{2}{*}{ Max } & \multirow{2}{*}{$\begin{array}{l}\text { Leaves } \\
\text { Mean }\end{array}$} & \multirow[b]{2}{*}{ (SD) } & \multirow[b]{2}{*}{ Min } & \multirow[b]{2}{*}{ Max } \\
\hline & & & & & & & & & & & & \\
\hline $\mathrm{Cd}$ & 0.20 & 0.00 & 0.20 & 0.20 & 0.40 & 0.00 & 0.20 & 0.40 & 0.33 & 0.12 & 0.20 & 0.40 \\
\hline $\mathrm{Pb}$ & 2.66 & 0.23 & 2.40 & 2.80 & 0.93 & 0.58 & 0.60 & 1.60 & 0.80 & 0.20 & 0.60 & 1.00 \\
\hline $\mathrm{Ni}$ & 50.26 & 0.50 & 49.73 & 50.73 & 18.73 & 0.42 & 49.73 & 50.73 & 27.00 & 1.97 & 25.40 & 29.20 \\
\hline Mn & 42.07 & 5.27 & 38.55 & 48.13 & 29.12 & 3.74 & 26.39 & 33.39 & 33.40 & 3.12 & 31.60 & 37.00 \\
\hline Co & 2.46 & 0.12 & 2.40 & 2.60 & 7.86 & 0.12 & 7.80 & 8.00 & 8.33 & 0.23 & 8.20 & 8.60 \\
\hline $\mathrm{Cr}$ & 65.11 & 1.31 & 63.91 & 66.51 & 62.64 & 0.61 & 61.98 & 63.18 & 56.80 & 0.53 & 56.40 & 57.40 \\
\hline $\mathrm{Cu}$ & 4.53 & 1.53 & 3.20 & 6.19 & 1.73 & 0.58 & 1.40 & 2.40 & 2.67 & 0.64 & 2.20 & 3.40 \\
\hline $\mathrm{Zn}$ & 4.59 & 0.00 & 4.59 & 4.59 & 2.40 & 0.00 & 2.40 & 2.40 & 3.13 & 0.23 & 3.00 & 3.40 \\
\hline & \multicolumn{4}{|c|}{ Means (Standard deviation), $\mathrm{n}=3$} & \multicolumn{4}{|c|}{ Means (Standard deviation), $\mathrm{n}=3$} & & & & \\
\hline
\end{tabular}

\subsubsection{The bioaccumulation of $\mathrm{Cd}$ in the native grass}

The bioaccumulations of $\mathrm{Cd}$ in all three sections of $A$. congesta grass were variable (Table 2) and followed the order stem $>$ leaves $>$ root, giving total mean bioaccumulation of $0.93 \mathrm{mg} / \mathrm{kg}$ versus the $10 \mathrm{mg} / \mathrm{kg} \mathrm{Cd}$ concentration in mine tailings soil (Table 1). The Cd total accumulation of $0.93 \mathrm{mg} / \mathrm{kg}$ by $A$. congesta was 10 times below the $\mathrm{Cd}$ in mine tailings soil.

The $\mathrm{Cd}$ concentration in both mine tailings 1 and 2 in this study was far below the limit of $100 \mathrm{mg} / \mathrm{kg}$ as the guideline value of NJ DEP [16]. Cd has no 
known physiological function in plants and is a potential toxic metal (Bala and Setia [17]) and can negatively affect plant growth and development (Benavides et al. [18]) by altering the uptake of minerals by plants through its effects on the availability of minerals from the soil (Moreno et al. [19]). Furthermore, the recommended level of $\mathrm{Cd}$ in grasses intended for livestock grazing was 0.5 $\mathrm{mg} / \mathrm{kg}$ (Rajaganapathy et al. [20]). Thus this may be hazardous to livestock graze on the grass on the mine tailings.

The findings of this research in terms of $\mathrm{Cd}$ concentration upon which $A$. congesta grass grows are in agreement with the study of Cole and Smith [3] which has reported that $A$. congesta frequently occur over the slightly less toxic ground. Furthermore, the research findings are in agreement with the study of Milton et al. [21] which has observed low Cd concentration (much lower than $0.01 \mathrm{mg} / \mathrm{kg}$ ) in plants that grow in Irish mine tailings of which was the case with low $A$. congesta $(0.93 \mathrm{mg} / \mathrm{kg})$ bioaccumulation level in this study.

\subsubsection{The bioaccumulation of $\mathrm{Pb}$ in the native grass}

The bioaccumulation of $\mathrm{Pb}$ concentration varied in all the three sections of $A$. congesta (Table 2) and followed the order roots $>$ stem $>$ leaves giving total bioaccumulation of $4.40 \mathrm{mg} / \mathrm{kg}$ versus $14.13 \mathrm{mg} / \mathrm{kg}$ concentration in mine tailings soil (Table 1). As in the case of $\mathrm{Cd}, \mathrm{Pb}$ has no known physiological function in plants and is a potential toxin (Bala and Setia [17]). The excess $\mathrm{Pb}$ causes toxicity symptoms in plants such as stunted growth, chlorosis and blackening of root system, inhibiting the photosynthesis process, upsets mineral nutrition and water balance (Sharma and Dubey [22]). The Pb levels in mine tailings 1 and 2 in this study were below the limit of $600 \mathrm{mg} / \mathrm{kg}$ (NJ DEP [16]). However, A. congesta thrived well at low $\mathrm{Pb}$ concentration under alkaline condition and low electrical conductivity. Maybe the high $\mathrm{Pb}$ concentration of $(17.57 \mathrm{mg} / \mathrm{kg})$ in the mine tailings 2 compounded by harsh alkaline condition of $\mathrm{pH}(8.94)$ inhibited growth of vegetation at this site.

As a result the research findings in terms of $\mathrm{Pb}$ concentration upon which $A$. congesta grass can tolerate and grow are in agreement with the study of Cole and Smith [3]). The research findings in terms of bioaccumulation of $\mathrm{Pb}(4.40$ $\mathrm{mg} / \mathrm{kg}$ ) by $A$. congesta are in agreement with the study of Mulugisi et al. [10] who found approximately the same concentration of $\mathrm{Pb}(4.2 \mathrm{mg} / \mathrm{kg})$ in Paspalum dilatatum grass species that grew in acidic New Union Gold Mine tailings.

\subsubsection{The bioaccumulation of $\mathrm{Ni}$ in the native grass}

The uptake of $\mathrm{Ni}$ by three sections of $A$. congesta was variable as well (Table 2) and followed the order roots $>$ leaves $>$ stem giving the total bioaccumulation of $95.99 \mathrm{mg} / \mathrm{kg}$ versus $114.62 \mathrm{mg} / \mathrm{kg}$ in mine tailings soil (Table 1). The $A$. congesta appears to have the ability to bioaccumulate the high concentration of Ni. However, the adverse elevated Ni concentration of $959.31 \mathrm{mg} / \mathrm{kg}$ in mine tailings 2 compounded by harsh alkaline condition of $\mathrm{pH}$ (8.94) maybe inhibiting vegetation growth as indicated by Palacios et al. [23]. Nickel, at low concentrations, was used by the plants as a micronutrient but at high concentrations maybe toxic. Furthermore, vegetation thrives well in soil with low Ni concentration of $114.62 \mathrm{mg} / \mathrm{kg}$ under favourable alkaline condition of $\mathrm{pH}$ 
7.97. The results in $\mathrm{Ni}$ concentration in the mine tailings 1 and 2 indicated that there was a statistically significant difference $(p<0.05)$ between the two mine tailings.

The research findings of this study are in agreement with the study of Cole and Smith [3] who reported that $A$. congesta frequently observed in less toxic sites. The research findings of Ni concentration of $27.00 \mathrm{mg} / \mathrm{kg}$ by A. congesta leaves are higher than the study of Maiti et al. [24] who found that Acacia mangium leaves were able to bioaccumulate Ni concentration of $10.86 \mathrm{mg} / \mathrm{kg}$. The difference may be explained by a combination of factors such as the Acacia mangium was grown in acidic mine tailings whereas $A$. congesta was growing in alkaline mine tailings and also the difference in plant physiology between the two plant species. Alternatively may be that the some plants can develop mechanisms to avoid the uptake of toxic elements or exclude them (Baker and Brooks [25]).

\subsubsection{The bioaccumulation of $\mathrm{Mn}$ in the native grass}

The bioaccumulation of $\mathrm{Mn}$ in sections of $A$. congesta grass were different (Table 2) and followed the order roots $>$ leaves $>$ stem giving the grass total mean accumulation of $104.592 \mathrm{mg} / \mathrm{kg}$ versus $498.78 \mathrm{mg} / \mathrm{kg}$ in mine tailings soils. $\mathrm{Mn}$ is one of the most essential elements for plant growth but like any other trace elements at elevated concentration may become toxic to plants. Though the Mn levels in mine tailings 2 were fairly low, the adverse alkaline conditions may have inhibited plant growth at this site (Table 1). The results in Mn concentration in the mine tailings 1 and 2 indicated that there was a statistically significant difference $(\mathrm{p}<0.05)$ between the two mine tailings.

The research findings showed that $A$. congesta was able to bioaccumulate $\mathrm{Mn}$ concentration of $104.592 \mathrm{mg} / \mathrm{kg}$ which was less compared to Hyparrhenia grass which bioaccumulate $533.716 \mathrm{mg} / \mathrm{kg}$ (Magonono et al. [26]). The differences in Mn bioaccumulation between the two grass may be probable be due to the differences in $\mathrm{Mn}$ bioaccumulation capability between the two grasses compounded by the $\mathrm{pH}$ variation between the two mine tailings since Hyparrhenia grass was growing in acidic mine tailings of New Union Gold Mine and also the differences in plant physiology.

\subsubsection{The bioaccumulation of $\mathrm{Co}$ in the native grass}

The bioaccumulation of $\mathrm{Co}$ in sections of $A$. congesta was different (Table 2) and followed the order roots $>$ stem $>$ leaves giving the grass total mean bioaccumulation of $18.66 \mathrm{mg} / \mathrm{kg}$ versus $77.10 \mathrm{mg} / \mathrm{kg}$ in mine tailings soil (Table 2). The Co has beneficial effects on the plant physiology which are responsible in improving plant growth (Jayakumar et al. [27]). This high Co concentration could probably be enough essential nutrients to promote vegetation growth aided by suitable alkaline condition (7.97), while the high alkaline condition $\mathrm{pH}(8.94)$ in mine tailing 2 with Co concentration $(63.44 \mathrm{mg} / \mathrm{kg})$ maybe inhibiting plant growth. The results in Co concentration in the mine tailings 1 and 2 indicated that there was a statistically significant difference $(p<0.05)$ between the two mine tailings. 
The research findings show that $A$. congesta was able to accumulate more Co at a concentration of $18.65 \mathrm{mg} / \mathrm{kg}$ in comparison to Paspalum dilatatum grass which accumulated $1.8 \mathrm{mg} / \mathrm{kg}$ in an acidic mine tailings (Mulugisi et al. [10]). The differences in Co bioaccumulation between the two grasses could be probable due to differences in Co concentration between the two mine tailings, the effect of $\mathrm{pH}$ and differences in plant physiology. The study by Mulugisi et al. [10] found low Co concentration of $1.8 \mathrm{mg} / \mathrm{kg}$ in the acidic mine tailings soil.

\subsubsection{The bioaccumulation of $\mathrm{Cr}$ in the native grass}

The bioaccumulation of $\mathrm{Cr}$ in sections of $A$. congesta was variable (Table 2) and followed the order roots $>$ stem $>$ leaves giving the grass total mean bioaccumulation of $184.55 \mathrm{mg} / \mathrm{kg}$ versus $81.30 \mathrm{mg} / \mathrm{kg}$ in mine tailings soil (Table 1). The concentration of $\mathrm{Cr}$ in both mine tailings 1 and 2 were all below NJ DEP [16] limit of $100 \mathrm{mg} / \mathrm{kg}$. Though the study was on total $\mathrm{Cr}$ concentration, $\mathrm{Cr}^{3+}$ species might be beneficial to the plant as opposed to $\mathrm{Cr}^{6+}$ which is toxic. It appears that $A$. congesta grass may bioaccumulate large quantities of $\mathrm{Cr}$ without any effect (shown by grass thriving at mine tailings 1) but is dependable on low alkaline conditions. However at adverse alkaline conditions, as those in mine tailings $2, \mathrm{Cr}$ probably becomes toxic and there is no plant growth (Dixit et al. [28]). Though $A$. congesta did bioaccumulate $\mathrm{Cr}$ it may not be truly classified as a hyper accumulator as per definition by Baker and Brooks [25]. In addition, $\mathrm{Cr}$ may be phototoxic either at all concentrations or above certain threshold levels (Nieboer and Richardson [29]). Cr phytotoxicity can result in inhibition of seed germination, degrade pigment status, nutrient balance, antioxidant enzymes and induce oxidative stress in plants (Panda [30]). The results in $\mathrm{Cr}$ concentration in the mine tailings 1 and 2 indicated that there was a statistically significant difference $(\mathrm{p}<0.05)$ between the two mine tailings.

The research findings show that $A$. congesta leaves was able to bioaccumulate almost 10 times more of $\mathrm{Cr}$ concentration of $56.80 \mathrm{mg} / \mathrm{kg}$ in comparison to Acacia mangium leaves which accumulated $5.7 \mathrm{mg} / \mathrm{kg}$ in acidic mine tailings (Maiti et al. [24]). The differences in Cr bioaccumulation between the two plants could be probable due to effect of $\mathrm{pH}$ and differences in plant physiology and differences in $\mathrm{Cr}$ levels in the mine tailings soils.

\subsubsection{The bioaccumulation of $\mathrm{Cu}$ in the native grass}

The bioaccumulation of $\mathrm{Cu}$ in three sections of $A$. congesta was different (Table 2) and followed the trend roots $>$ leaves $>$ stem giving grass total mean bioaccumulation of $8.93 \mathrm{mg} / \mathrm{kg}$ versus $26.32 \mathrm{mg} / \mathrm{kg}$ in mine tailings soil (Table $1)$. The $A$. congesta grass was able to thrive well in soil with high $\mathrm{Cu}$ concentration under favourable low alkaline condition whereas the adverse alkaline conditions of $\mathrm{pH} 8.94$ inhibited vegetation growth in mine tailings 2 .

The research findings show that $A$. congesta was able to bioaccumulate more of $\mathrm{Cu}$ at a concentration of $18.93 \mathrm{mg} / \mathrm{kg}$ in comparison with Paspalum dilatatum which was able accumulate $40.3 \mathrm{mg} / \mathrm{kg}$ of $\mathrm{Cu}$ in an acidic mine tailings soils (Mulugisi et al. [10]). The reason might be that the $\mathrm{Cu}$ bioaccumulation between the two grasses could be probable due to differences in absorption capability of $\mathrm{Cu}$ by the two grasses and the different $\mathrm{pH}$ conditions with one being acidic 
(New Union Gold Mine tailings) while the other one being alkaline (Nyala Magnesite mine tailing) and also the differences in plant physiology.

\subsubsection{The bioaccumulation of $\mathrm{Zn}$ in the native grass}

The accumulation of $\mathrm{Zn}$ in three sections of $A$. congesta grass was variable (Table 2) and followed the trend roots $>>$ leaves $>$ stem giving grass total mean bioaccumulation of $10.12 \mathrm{mg} / \mathrm{kg}$ versus $58.31 \mathrm{mg} / \mathrm{kg}$ in mine tailings soil (Table 1). The concentration of $\mathrm{Zn}$ in both mine tailings 1 and 2 were all below NJ DEP [16] limit of $1500 \mathrm{mg} / \mathrm{kg}$. However, the $A$. congesta grass was able to thrive well in soil with high $\mathrm{Zn}$ concentration under favourable low alkaline condition $(\mathrm{pH}$ =7.97). There was no plant growth in mine tailings 2, though with low Zn levels but adverse alkaline conditions $(\mathrm{pH}=8.94)$ probably inhibitory factor. The results in $\mathrm{Zn}$ concentration in the mine tailings 1 and 2 indicated that there was a statistically significant difference $(\mathrm{p}<0.05)$ between the two mine tailings.

The research findings show that $A$. congesta was able to bioaccumulate less $\mathrm{Zn}$ at a concentration of $10.12 \mathrm{mg} / \mathrm{kg}$ in comparison with Paspalum dilatatum which accumulated more than $35.6 \mathrm{mg} / \mathrm{kg}$ of $\mathrm{Zn}$ when growing in an acidic mine tailings soil (Mulugisi et al. [10]). The differences in $\mathrm{Zn}$ bioaccumulation between the two grasses may probable be due to differences in absorption capability of $\mathrm{Zn}$ by the two grasses and the different $\mathrm{pH}$ conditions with one being acidic (New Union Gold mine tailings) while the other one being alkaline (Nyala Magnesite mine tailing) and differences in plant physiology.

\subsection{Bioaccumulation coefficient of toxic metals in $A$. congesta grass}

The bioaccumulation coefficient (BAC) is defined as a ratio of toxic metals concentration in different section of plants (i.e. roots stem and leaves) to toxic metals concentration in the soil (Conesa et al. [31]). If the plants have the bioaccumulation coefficient greater than one $(>1)$ it can be defined as the hyperaccumulator plants (Conesa et al. [32]). It appears that $A$. congesta grass species in this study does not qualify for this definition to be classified hyperaccumulators for all analysed heavy metal with exception of $\mathrm{Cr}$ (Figure 2). Bioaccumulation coefficient (BAC) in the A. congesta grass at Nyala mine

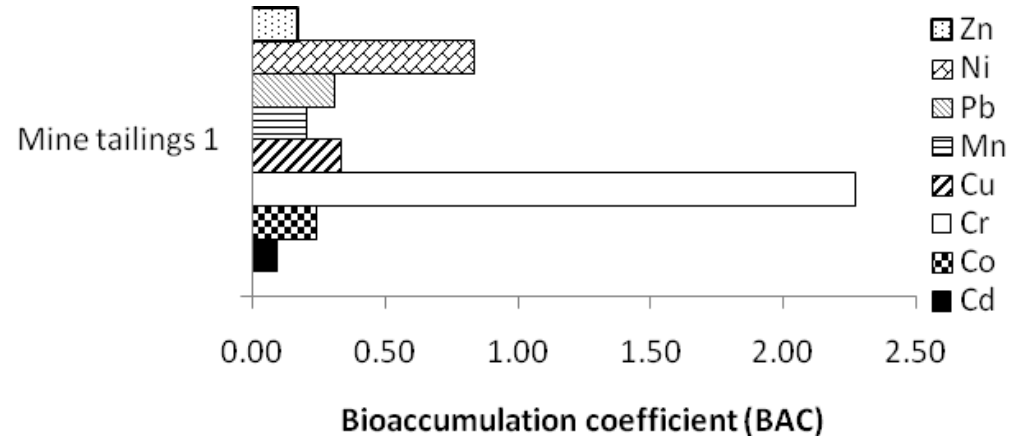

Figure 2: The bioaccumulation coefficient (BAC) of $A$. congesta. 
tailings of the analysed trace elements was recorded. Therefore, A. congesta is hyperaccumulator of $\mathrm{Cr}$ only. The aspect of phytoremediation includes the removal of metal through hyper-accumulation and stabilisation of soil and binding such that soil erosion is minimised (Conesa et al. [33]).

\section{Conclusion}

The study showed that there were trace and toxic metals, $\mathrm{Co}, \mathrm{Cr}, \mathrm{Cd}, \mathrm{Cu}, \mathrm{Mn}$ and $\mathrm{Zn}$ at the mine tailings soil. Mine tailing 2 revealed high alkaline condition of $\mathrm{pH}$ of 8.94 and a low EC $(1.88 \mathrm{mS} / \mathrm{cm})$ values and consequently classified as sodic tailing which provides poor structure for plant growth. With mine tailing 1 with a slight alkaline $\mathrm{pH}$ of (7.97) and high EC $(4.92 \mathrm{mS} / \mathrm{cm})$ and consequently classified as saline tailing which was able to promote plant growth. The native grass, $A$. congesta grass was able to bioaccumulate the following metals, $\mathrm{Co}, \mathrm{Cr}$, $\mathrm{Cd}, \mathrm{Cu}, \mathrm{Mn}$ and $\mathrm{Zn}$ under mild alkaline conditions. The native grass has the potential to act as phytoremediation agent to cover exposed mine tailings and minimise water and wind erosion thus preventing the contamination of water sources and nearby agricultural fields.

\section{Acknowledgement}

The University of Venda gave financial support for the study project (I431) and travel costs (IP60) to attend and present at the $11^{\text {th }}$ International Conference on Modelling, Monitoring and Management of Water Pollution, New Forest, United Kingdom.

\section{References}

[1] Truong, P.N.V., Vetiver grass technology for mine rehabilitation. Resource Sciences Centre, Queensland Department of Natural Resources. Brisbane, Australia, 1999.

[2] Adriano, D.C., Trace elements in the terrestrial Environment. SpringerVerlag, New York, pp. 5533, 1986.

[3] Cole, M.M., and Smith, R.F., Vegetation as Indicator of Environmental Pollution. Transactions of the Institute of British Geographers, New Series. 9: 477-493, 1984.

[4] Wislocka, M., Krawczyk, J., Klink, A., Morrison, L.,. Bioaccumulation of Heavy Metals by selected plant species from Uranium Mining Dumps in the Sudety Mountains. Poland. Polish J. of Environmental Studies, 15: 811-812, 2006.

[5] Truong, P.N., and Baker D., Vetiver Grass System for environmental protection. Technical Bulletin No. 1998/1. Pacific Rim Vetiver Network, Bangkok, Thailand, 1998.

[6] McBride, M.B., Ion exchange. In: McBride M.B. Environmental chemistry of soils, Oxford University Press, New York. 279p, 1994. 
[7] Bauer, A., W.A. Berg, and Gould, W.L., Correction of nutrient deficiencies and toxicities in Strip-mined lands in Semi-arid and arid regions. Chapter 25, Reclamation of Drastically disturbed lands, Edited by F.W. Schaller and p. Sutton. Madison, Wis..American Society of Agronomy, p451-466, 1978.

[8] Thulamela Municipality Report, Government Printers, South Africa, 1998.

[9] Department of Water Affairs and Forestry (DWAF). South Africa water quality guidelines second edition. Volume 6: agricultural use: aquaculture. DWAF, 15-185p, 1996.

[10] Mulugisi, G., Gumbo, J.R., Dacosta, F.A., and Muzerengi, C., Evaluating the suitability of Paspalum as a candidate for Rehabilitation of Mine Tailings dams: A Case study of New Union Gold Mine. Procd. International Mine Water Conference, p499, 2010.

[11] APHA., Standard Methods for the Examination of Water and Wastewater, Washington, DC, USA, 2006.

[12] Van Rensburg, L., Maboeta, M.S., Morgenthal, T.L., Rehabilitation of codisposed diamond tailings: growth medium rectification procedures and indigenous grass establishment. Water, Air Soil Pollution, 154: 101-113, 2004.

[13] Kamphorst, A. and Bolt, G.H., Saline and sodic soils. In G.H. Bolt and M.G.M. Bruggenwert (eds.), Soil Chemistry. A Basic Elements. Amsterdam, Oxford, New York. Elsevier, p171-191, 1976.

[14] Larcher, W., Water relation. In: Physiological plant ecology. 2nd ed. Springer-Verlag, New York, p303, 1980.

[15] Lasat, M.M., The Use of Plants for the Removal of Toxic Metals from Contaminated Soil. Plant Physiology. 118, 875-883, 1996.

[16] NJ DEP, Soil Cleanup Criteria. New Jersey Department of Environmental Protection. Proposed Cleanup Standards for Contaminated Sites, NJAC 7:26D, 1996.

[17] Bala, R., and Setia, R.C., Some aspects of cadmium and lead toxicity in plants. In: Malik, C.P., Setia R.C., and Singh, P., (ed.) Advances in Frontier Areas of Plant Sciences. Narendra Publishing House. p. 167, 1990.

[18] Benavides, M.P., Gallego, S.M., Tomaro, M.L., Cadmium toxicity in plants. The Brazilian Journal of plant Physiology, 17: 49-55, 2005.

[19] Moreno, J.L., Hernandez, T., Garcia, C., Effects of a cadmium-containing sewage sludge compost on dynamics of organic matter and microbial activity in an arid soils. Biology and Fertility of Soils, 28:230-237, 1999.

[20] Rajaganapathy, V., Xavier, F., Sreekumar, D., Mandal, P.K., Heavy metal Contamination in Soil, Water and Fodder and their Presence in Livestock and Products: A Review. Journal of Environmental Science and Technology, 4: 234-249, 2011.

[21] Milton, A., Cooke, J.A., and Johnson, M.S., A Comparison of Cadmium in Ecosystems on Metalliferous Mine Tailings in Wales and Ireland. Water, Air and soil pollution Journal, 153: 161-162, 2002.

[22] Sharma, P., and Dubey, R.S., Toxic metals in plants, lead toxicity in plants. Brazilian Journal of plant physiology, 17: 35-57, 2005. 
[23] Palacios, G., Gomez, I., Moral, R., and Mataix, J., Nickel accumulation in tomato plants: effect on plant growth. Fresenius environ. Bull, 4: 469-474, 1995.

[24] Maiti, S.K., Sinha, I.N., and Nandhini, S. Micronutrient mobility and heavy metal uptake in plants growing on acidic coalmine dumps. In Procd. of Nat. Sem. on Envt. Engg. with special emphasis on Mining Env, p316-326, 2004.

[25] Baker, A.J.M. and Brooks, R.R.., Terrestrial higher plants which hyperaccumulate metallic elements- A review of their distribution, ecology and phytochemistry. Biorecovery, 1: 81-126, 1989.

[26] Magonono, F.A., Gumbo, J.R., Chigayo, K., Dacosta, F.A., Mojapelo, P., Bioaccumulation of Toxic Metals by Hyparrhenia Grass Species: A Case Study of New Union Gold Mine Tailings and Makhado Town, Limpopo, South Africa. Procd. International Mine Water Conference, p603-608, 2011.

[27] Jayakumar, K., Jaleel, C.A., and Vijayarengan, P., Effect of Different Concentrations of Cobalt on Pigment Contents of Soybean. Botany Research International, 2: 153-156, 2009.

[28] Dixit, V., Pandey, V., Shyam, R., Chromium ions inactivate electron transport and enhance superoxide generation in vivo in pea (Pisum sativum L. Cv. Azad) root mitochondria. Plant, Cell and Environment, 25: 6876693, 2002.

[29] Nieboer E., and Richardson D.H.S., The replacement of the nondescript term 'heavy metal' by biologically significant and chemically significant classification of metal ions. Environmental Pollution, 1:3-26, 1980.

[30] Panda, S.K., Heavy metal phytotoxicity induces oxidative stress in Taxithelium sp. Current Science, 84: 631-633, 2003.

[31] Conesa H.M., Faz, A., and Arnaldos R., Heavy metal accumulation and tolerance in plants from mine tailings of the semiarid Cartagena-La Union mining district (SE Spain). Science of the Total Environment, 366: 1-11, 2006.

[32] Conesa H.M., Garcia. G., Faz, A., and Arnaldos R., Dynamics of metal tolerant plant communities' development in mine tailings from the Cartagena-La Union Mining District (SE Spain) and their interest for further revegetation purposes. Chemosphere, 68: 1180-1185, 2007.

[33] Conesa, H.M., Moradi, A.B, Robinon, B.H., Kuhne, G., Lehmann, E., Schulin R., Response of native grasses and Cicer arietinum to soil polluted with mining wastes: Implications for the management of land adjacent to mine sites. Environmental \& Experimental Botany, 65: 198-204, 2009. 